\title{
Effects of supplementary irrigation on chemical and physical soil properties in the rolling pampa region of Argentina
}

\author{
Rodolfo Mon ${ }^{1}$, Carlos Irurtia ${ }^{1}$, Guido Fernando Botta ${ }^{2}$, Oscar Pozzolo ${ }^{3}$, \\ Fernando Bellora Melcón ${ }^{2}$, David Rivero ${ }^{4}$, and Miguel Bomben ${ }^{4}$ \\ ${ }^{1}$ Instituto Nacional de Tecnología Agropecuaria (INTA), Instituto de Suelos \\ Castelar, Provincia de Buenos Aires Argentina. ${ }^{2}$ Facultad de Agronomía de la Universidad de Buenos Aires, \\ Av. San Martín, 4453 C.P. 1417, Ciudad Autónoma de Buenos Aires, Argentina. \\ ${ }^{3}$ Instituto Nacional de Tecnología Agropecuaria (INTA) Concepción del Uruguay, Provincia de Entre Ríos \\ Argentina. ${ }^{4}$ Facultad de Agronomía Universidad Nacional de La Pampa, C.P. 6300, La Pampa, Argentina.
}

\begin{abstract}
R. Mon, C. Irurtia, G. F. Botta, O. Pozzolo, F. Bellora Melcón, D. Rivero, and M. Bomben. 2007. Effects of supplementary irrigation on chemical and physical soil properties in the rolling pampa region of Argentina. Cien. Inv. Agr. 34(3):187-194. The effects of supplementary irrigation on soil chemical and physical properties were studied in 21 locations in the north of the rolling pampa region of Argentina. The chemical and physical variables were measured in top soil $(0-100 \mathrm{~mm})$ to compare irrigated and non-irrigated soils. Chemical variables were: electrical conductivity (EC), $\mathrm{pH}$, exchangeable sodium percentage (ESP), and organic mater content. Physical variables included structural index (SI) and percolation index (PI) measured in the laboratory, as well as infiltration, runoff, and soil losses, measured in the field with a small portable rainfall simulator. Water quality was established according to its chemical composition and Riverside USA classification. In irrigated soils, chemical data shows, on average, a slight increase in ESP (from 2.56 to 5.52) and in pH (from 6.13 to 6.45). EC, SI, and PI show the same values in irrigated and non-irrigated soils. The application of a simulated rainfall of $30 \mathrm{~mm}$ in $30 \mathrm{~min}$ revealed a different soil behavior. Irrigated soils present lower values of water entry and infiltration rates, and higher values of runoff and soil losses. The variation in chemical and physical soil properties show that within 10 years of supplementary irrigation a slight process of sodication and alkalinization occurs. Water quality and soil chemical data suggest that the sodication process and the increased soil erosion risk must be controlled in order to achieve a sustainable high production system.
\end{abstract}

Keywords: Erosion risk, infiltration, sodication, supplementary irrigation.

\section{Introduction}

In the last decade, farmers in the wet pampa region of Argentina, a region with longterm continuous agriculture, began using supplementary irrigation to avoid water stress during critical periods. Crop growth is usually affected during the summer by short periods of water deficit that significantly decrease crop yields.
Supplementary irrigation is needed when natural precipitation is not adequate to secure grain and forage production (Abu-Awwad and Kharabsheh, 2000). Depending on the size of the farm and the type of irrigation system, application of water is often made possible by using modern power sources from deep well pumps and storage of large quantities of water in reservoirs, ponds, streams and rivers. City water is also often accessed directly by small farmers who use drip irrigation for their vegetable gardens.

Soil and water losses by erosion and runoff must 
be controlled in order to allow for sustainable agriculture. In Georgia, on relatively sandy soil with low organic matter content, Truman and Rouland (2005) found high erosion risk when a supplementary irrigation system was used. Natural water has different salt concentrations and qualities, and contains principally salts of high solubility like sodium, calcium, magnesium and potassium chlorides and sulfates.

Salinization and sodication could limit the soil's productivity, leading to fertility reduction (Al$\mathrm{Zu}$ 'bi, 2007). If the level of $\mathrm{Na}^{+}$in the soil is high, the colloidal fraction behavior will be affected. The level of $\mathrm{Na}^{+}$in soil is usually quantified by the exchangeable sodium percentage (ESP) or by its estimator, the sodium adsorption ratio SAR. When SAR increases, then the rate of the soil sodication process also increases (Herrero and Perez Covetta, 2005).
Suarez et al. (2006) found that a SAR increase caused by irrigation water had an adverse impact on water infiltration for two types of soil, clay and loam. For the clay soil, even an increase from SAR 2 to SAR 4 resulted in a significant increase in infiltration rate, while in loam soil the increase in infiltration time was significant. Sodic soils are associated with structural changes that principally affect soil's permeability. With high ESP and low electrolyte concentration, clay, as well as organic matter, begins to swell and disperse, causing negative physical effects such as restricted aeration and permeability.

Damage to physical properties soon appears at low salt concentrations. Clay and organic matter swelling and dispersion are unavoidable after irrigation with water of low quality (Kamphorst and Bolt, 1978). Boivin et al. (2002) found that

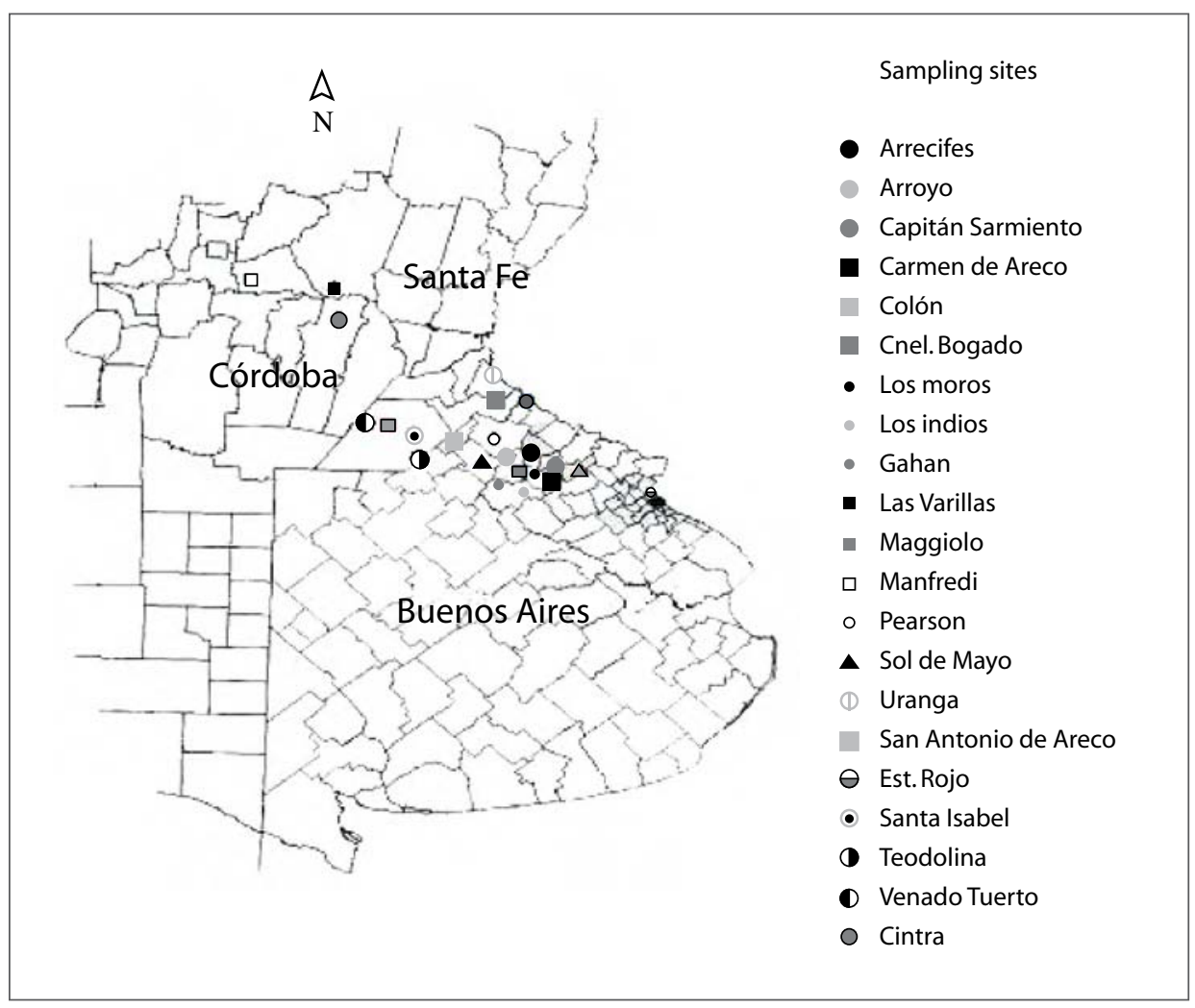

Figure 1. Soil and water control sites in the selected area under supplementary irrigation in the pampa Region of Argentina.

Figura 1. Sitios de muestreo de agua y suelos en el área elegida bajo riego suplementario en la región de la pampa de Argentina. 
the increase in alkalinity and $\mathrm{Mg}$ concentration in arid vertisol soil was caused partly by the composition of the irrigation water, and partly by the reduction and dissolution of Fe oxides, and $\mathrm{Fe}^{2+}$ fixation on exchange sites of the clay minerals.

Hydraulic conductivity (k) reduction is irreversible, or very difficult to restore, because of soil matrix changes caused by swelling and dispersion of clay and organic matter. Chen and Banin (1975) used microscopic observation to show that fine particle reorganization arranges a continuous net of fine material that fills all the void spaces.

The salt effect on soil hydraulic properties should not be ignored because it can lead to great mistakes in soil management with irrigation (Dane and Klute 1977). The changes in clay dispersion and hydraulic conductivity are very sensitive to low ESP and salinity levels (Shainberg et al., 1984). On the other hand, Génova (1993) did not detect negative effects on soils in the pampean region when farms were irrigated with carbonated water, suggesting that in deep, well drained and calcium rich soils, sodication is controlled by natural processes.

Cerana (1980) found that that high osmotic pressure in external soil solution limits water entrance to interlaminar space, but at low salinity the clay swelling separates sheets more and more. When ESP reaches $15-20 \%$ and external solution concentration is very low, fragmentation of clay crystals occurs, developing impervious horizons. This author found infiltration reduction rates of $85 \%$ to $46 \%$, with a remarkable colloid dispersion, after 8 years of supplementary irrigation in Entic Haplustolls soils under supplementary irrigation in the north of the pampas region. In these soils, the ESP value changed from 1.3 2.0 to $4.5-7.4 \%$.

In the south of pampa region, Costa (2000) advised that changes in sodicity were persistent, but tended to stabilize between SAR $=5$ and $\mathrm{SAR}=7$. When irrigation was discontinued for a year and $1129 \mathrm{~mm}$ of rainfall leached the soil, the SAR value decreased from 5.3 to 1.8. The objective of this work was to assess water irrigation impact on soil properties after 10 years of supplementary irrigation in a large area dedicated to grain production in the rolling pampa region of Argentina.

\section{Material and methods}

This study was performed in one of the most important areas under supplementary irrigation in Argentina, located north of Buenos Aires $\left(39^{\circ} 15^{\prime} \mathrm{S}, 59^{\circ} 21^{\prime} \mathrm{W}\right)$ and south of Córdoba $\left(33^{\circ} 10^{\prime} \mathrm{S}, 63^{\circ} 40^{\prime} \mathrm{W}\right)$ and Santa Fe (32 $3^{\circ}$, $61^{\circ} 17 \mathrm{~W}$ ) provinces (Figure 1). This area is characterized by a temperate climate with deep and fertile soils originated in a thick layer of loess. The annual rainfall distribution was very variable during the 10 year period of this study (1996-2005) (Figure 2).

This area was studied in order to select control points on farms with supplementary irrigation, and to analyze irrigation effects on physical and chemical soil properties. The prevailing soils in the eastern areas were Argiudolls (Pergamino soil) and in the southwestern area were Hapludolls (Santa Isabel soil) (INTA 1972). These soils, located in the rolling pampa region, are medium textured, deep, fertile and generally can hold large amounts of water (Table 1). They support the Argentine grain production, typically producing high yields of maize, soybeans, wheat and sunflower. However, in some drier months, supplementary irrigation is necessary for optimum productivity.

\section{Water quality}

Water used for supplementary irrigation is taken from wells, 40 to $120 \mathrm{~m}$ deep, that supply water from a much extended aquifer, Puelches. This aquifer consists of a deposit of fluvial silts of sandy grain, with maximum flows of $200 \mathrm{~m} \cdot \mathrm{h}^{-1}$. In general, water is rich in calcium-magnesiumsodium bicarbonate salts. The annual average sheet applied is 150 to $300 \mathrm{~mm}$, mainly in summer (December, January and February), to control short periods of water stress caused by the high temperatures in those months.

\section{Chemical and physical soil data}

Chemical and physical parameters were 


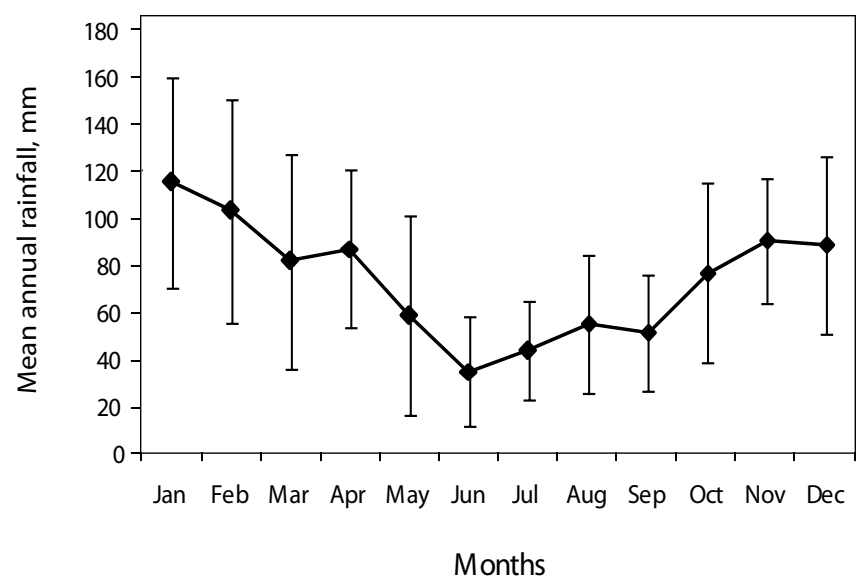

Figure 2. Mean annual rainfall registered north of Buenos Aires and south of Córdoba and Santa Fe provinces between 1996 and 2005. Each point is the mean of 10 years. Bars = standard deviation.

Figura 2. Precipitación promedio anual entre 1996 y 2005 registradas en el norte de Buenos Aires y sur de las provincias de Córdoba y Santa Fe. Cada punto es el promedio de 10 años. Barras = desvío estándar.

measured in the topsoil $(0-100 \mathrm{~mm})$ to compare irrigated soils with non-irrigated soils in the same locations. Chemical parameters were electrical conductivity (EC), $\mathrm{pH}$, exchangeable sodium percentage (ESP; determined according to U.S. Salinity Laboratory Staff recommendations, 1954) and organic mater content (OM; Walkley and Black method 1964). Physical parameters were structural index (SI; De Boodt and De Leenheer method, 1967) and percolation index (PI), measured in the laboratory (Henin method, 1969), as well as infiltration (I), runoff (RO), and soil losses $(\mathrm{L})$, measured in the field with a small portable rainfall simulator.

\section{Infiltration of simulated rainfall}

Infiltration, runoff and soil losses were measured in the field with a small portable rainfall simulator (Irurtia and Mon, 1994). This device is $150 \mathrm{~cm}$ high, has a measurement area of $625 \mathrm{~cm}^{2}$ and a rainfall intensity capacity of 10 to $300 \mathrm{~mm} \cdot \mathrm{h}^{-1}$. The selected rainfall for all the treatments was a sheet of $30 \mathrm{~mm}$, applied with an intensity of $60 \mathrm{~mm} \cdot \mathrm{h}^{-1}$ over $30 \mathrm{~min}$, with four replications. Runoff volumes collected in 5 min intervals were used to calculate infiltration and runoff rates. Sediment production was also measured by desiccation and gravimetric measures of the collected runoff. The water quality was determined by taking samples from the sprinklers or water pumps.

\section{Design and statistical analysis}

Two treatments were established at each sampling site (60000 $\mathrm{m}^{2}$ each site): 1 . Soil under supplementary irrigation (pivot systems), and 2. Non-irrigated soils. A completely randomized factorial design with four replications was used, comprised of two irrigation treatments and two soil types (Arguidol, Pergamino soil and Hapludoll, Santa Isabel soil). Data was subjected to analysis of variance (ANOVA), and means were separated according to Duncan's multiple range test using the SAS program (SAS Institute, Cary, NC, USA) (Botta et al., 2006).

\section{Results and discussion}

\section{Chemical and physical soil data}

Supplementary irrigation leads to significant variations in some of the studied parameters. Electrical conductivity (EC) and organic matter content $(\mathrm{OM})$ remained steady in both treatments. $\mathrm{pH}$ increased, but remained lower 
Table 1. Soil profile characteristics of the Argiudoll and Hapludoll soils

Cuadro 1. Características del perfil del suelo Argiudol y Hapludol.

\begin{tabular}{|c|c|c|c|c|c|c|c|c|}
\hline \multirow[b]{2}{*}{ Characteristic } & \multicolumn{4}{|c|}{ Arguidol (Pergamino soil) } & \multicolumn{4}{|c|}{ Hapludoll (Santa Isabel soil) } \\
\hline & $\mathrm{A}$ & B1 & B21t & $\mathrm{B} 22 \mathrm{t}$ & A & B1 & $\mathrm{B} 21 \mathrm{t}$ & $\mathrm{B} 22 \mathrm{t}$ \\
\hline Depth range, mm & $0-250$ & $250-340$ & $340-750$ & $750-950$ & $0-200$ & $200-360$ & $360-670$ & $670-980$ \\
\hline Organic matter, $\%$ & 3.0 & 1.5 & 1.1 & 0.6 & 2.2 & 1.6 & 1.0 & 0.4 \\
\hline Clay $(<2 \mathrm{~m}), \%$ & 23 & 30 & 44 & 30 & 16 & 24 & 21 & 17 \\
\hline Silt $(2-20 \mathrm{~m}), \%$ & 65 & 57 & 48 & 56 & 43 & 39 & 40 & 43 \\
\hline Medium sand $(250-500 \mathrm{~m}), \%$ & 12 & 13 & 9 & 13 & 41 & 37 & 39 & 40 \\
\hline $\mathrm{pH}$ in $\mathrm{H}_{2} \mathrm{O}(1: 2.5)$ & 6.1 & 6.2 & 6.3 & 6.5 & 6.6 & 6.9 & 7.0 & 7.6 \\
\hline $\begin{array}{l}\text { Cation exchange capacity, } \\
\text { me } 1100^{-1}\end{array}$ & 20 & 19 & 32 & 27 & 15 & 19 & 17 & 16 \\
\hline $\begin{array}{l}\text { Exchangeable sodium } \\
\text { percentage, } \%\end{array}$ & 1.2 & 1.2 & 0.8 & 0.8 & 2.0 & 2.5 & 2.4 & 2.5 \\
\hline Electrical conductivity, $\mathrm{ds} \cdot \mathrm{m}^{-1}$ & 0.45 & 0.50 & 0.65 & 0.65 & 0.55 & 0.8 & 1.3 & 1.4 \\
\hline
\end{tabular}

than exchangeable sodium percentage (ESP). The average value of $\mathrm{pH}$ increased from 6.13 to 6.45 , and ESP increased from 2.56 to $5.52 \%$ (Table 2).

These results indicate that irrigation water increased the sodium content in soil without increasing the total salt content. This is a modification of the proportion of exchangeable cations, rather than an increase in total salt content. Apparently, the humid climate precludes salt concentration in soil by deep leaching and runoff. This is confirmed with the data of the Figure 2, especially in the years 1997 and 2000 to 2003, when the annual average rainfalls were greater than in other years.

This effect seems to be acceptable for desirable chemical soil conditions. However, it is known that high ESP values combined with low electrolyte levels are favorable for colloid (clay and organic matter) dispersion. In this case, according to Suarez et al. (2006), there would be a reduction in fertility, causing a decrease in the soil productivity, and physical soil properties would be affected.

Physical soil parameters, such as soil structural index (SI) and percolation index (PI) were not significantly different in irrigated and nonirrigated soils. The average value remained similar in both treatments. Nevertheless, SI (2.27 and $2.33 \mathrm{~mm})$, and PI (11.3 and $\left.11.7 \mathrm{~cm}^{-1} \mathrm{~h}^{-1}\right)$ are indicators of low physical conditions. According to Al-Zu'bi (2007), damages to soil's physical properties were probably produced by salt concentration in the irrigate water. These results differ from Genova (1993), in relation to the negative effects in pampean region soils to farms irrigated with carbonated waters. Obviously, supplementary irrigation was not the principal cause of the current soil degradation degree. In the zone where this work was carried out, about 50 years of land cropping without conservation planning led to high levels of physical degradation.

Table 2. Chemical and physical soil properties in irrigated and non-irrigated soils in the pampa Region of Argentina. Cuadro 2. Propiedades químicas y físicas de los suelo, irrigados y no irrigados en la región de la pampa de Argentina.

\begin{tabular}{|c|c|c|c|c|c|c|}
\hline Treatments & $\begin{array}{c}\mathrm{EC}^{1} \\
\mathrm{ds} \cdot \mathrm{m}^{-1}\end{array}$ & $\begin{array}{c}\mathrm{pH} \\
\text { in water }\end{array}$ & $\begin{array}{c}\mathrm{ESP}^{1} \\
\%\end{array}$ & $\begin{array}{c}\mathrm{OM}^{1} \\
\%\end{array}$ & $\begin{array}{l}\text { Structural } \\
\text { index } \\
\text { mm }\end{array}$ & $\begin{array}{c}\text { Percolation } \\
\text { index } \\
\mathrm{cm} \cdot \mathrm{h}^{-1}\end{array}$ \\
\hline Nonirrigated soil & $0.40 \mathrm{a}^{2}$ & $6.13 \mathrm{a}^{2}$ & $2.56 \mathrm{a}^{2}$ & $3.24 \mathrm{a}^{2}$ & $2.33 \mathrm{a}$ & $11.7 \mathrm{a}$ \\
\hline Irrigated soil & $0.45 \mathrm{a}$ & $6.45 \mathrm{a}$ & $5.52 \mathrm{~b}$ & $3.27 \mathrm{a}$ & $2.27 \mathrm{a}$ & $11.3 \mathrm{a}$ \\
\hline
\end{tabular}

${ }^{1}$ EC, electrical conductivity; ESP, exchangeable sodium percentage; OM, organic matter.

${ }^{2}$ Means followed by different letters in the same column are significantly different according to Duncan's multiple range test ( $\mathrm{p}<0.01$ ). 


\section{Infiltration of simulated rainfall}

Rainfall simulations point out significant differences in infiltration rates and sediment yields. Water entry, mean infiltration and final infiltration, show lesser values in irrigated soils, while sediment yields are higher (Table 3).

Water entry is limited, and under high rainfall, water-logging may occur on top of the impermeable layer. The total water entry in non-irrigated soils is $4.5 \mathrm{~mm}$ higher than in an irrigated soil; that means an increase of water storage of $15 \%$ of the total applied rain. In the same way, irrigated soils present a higher runoff that allows a significant increment in sediment yield. It's important to note that permeability declines during rain or irrigation when surface aggregates break down and are compacted under drop impact.

The average sediment value obtained in irrigated soil of $1.25 \mathrm{~g}\left(0.2 \mathrm{t}^{\mathrm{h}} \mathrm{ha}^{-1}\right)$ is double the $0.66 \mathrm{~g}\left(0.1 \mathrm{t}^{-\mathrm{ha}^{-1}}\right)$ obtained in non-irrigated soil. These results are in agreement with Truman and Rowland (2005), who showed that there is a higher soil erosion risk for lands under supplementary irrigation.

All the rainfall simulations were done on sunny days, and this must be considered fortuitous. Probably, soils under supplementary irrigation hold higher water content during long periods of drought without suffering consequences. On the contrary, non-irrigated soils usually suffer short periods of drought between one storm and the next, when dryer top soil conditions cause crack formation, improving structural conditions for water entry.

\section{Water quality}

Irrigation water quality was determined by water analysis in 21 sites (Figure 1, Table 4). On average, irrigation water presents $0.78 \mathrm{dS} \cdot \mathrm{m}^{-1}$ of electricalconductivity(EC), a sodiumadsorption ratio (SAR) of 9.98 and a residual sodium carbonate (RSC) of $5.99 \mathrm{me} \cdot \mathrm{L}^{-1}$. This water is classified by the U.S. Salinity Laboratory Staff as C3S2. This means that if this water is used in a traditional irrigation system, typical of arid lands, salinization and alkalinization hazards are high and the sodication hazard is medium. According to this classification, the quality of irrigation water used in the pampean region is almost unsuitable. This classification was not elaborated to classify waters for supplementary irrigation as used in the pampean region, and this must not be ignored. While salinization risk can be lowered by the $1000 \mathrm{~mm}$ annual rainfall, sodication is not controlled by the soil and climate system. Furthermore, the high RSC results in calcium precipitation and a $\mathrm{pH}$ rise. These questions suggest that gypsum addition is necessary to prevent soil sodication.

Within the limits of our experimental conditions, we can arrive at the following conclusions: Chemical and physical soil properties after 10 years of supplementary irrigation indicate a slight process of sodication and alkalinization. Nevertheless, the degree of physical degradation was the same in irrigated and non-irrigated soils, likely due to the initially low structural condition.

The application of a $30 \mathrm{~mm}$ rainfall shows that irrigated soils present higher values of runoff and sediment production. Water quality and

Table 3. Rainfall simulations: Water entry, mean and final infiltration, runoff and removed sediment after 30 min rainfall. Cuadro 3. Simulación de lluvia: Entrada de agua, infiltración media y final, escurrimiento y sedimento removido después de 30 min de precipitación.

\begin{tabular}{|c|c|c|c|c|c|}
\hline Treatments & $\begin{array}{l}\text { Water entry } \\
\mathrm{mm}\end{array}$ & $\begin{array}{c}\text { Mean rate } \\
\text { Infiltration } \\
\mathrm{mm} \cdot \mathrm{h}^{-1}\end{array}$ & $\begin{array}{c}\text { Final rate } \\
\text { Infiltration } \\
\mathrm{mm} \cdot \mathrm{h}^{-1}\end{array}$ & $\begin{array}{l}\text { Mean runoff } \\
\text { infiltration } \\
\mathrm{mm}\end{array}$ & $\begin{array}{c}\text { Mean } \\
\text { sediments } \\
\mathrm{kg} \cdot \mathrm{ha}^{-1}\end{array}$ \\
\hline $\begin{array}{l}\text { Non irrigated soil } \\
\text { Irrigated soil }\end{array}$ & $\begin{array}{l}23.0 \mathrm{a}^{1} \\
18.5 \mathrm{~b}\end{array}$ & $\begin{array}{l}46.0 \mathrm{a}^{1} \\
37.0 \mathrm{~b}\end{array}$ & $\begin{array}{l}36.5 \mathrm{a}^{1} \\
23.8 \mathrm{~b}\end{array}$ & $\begin{array}{r}7.0 \mathrm{a}^{1} \\
11.5 \mathrm{~b}\end{array}$ & $\begin{array}{l}105.6 \mathrm{a}^{1} \\
200.1 \mathrm{~b}\end{array}$ \\
\hline
\end{tabular}

${ }^{1}$ Means followed by different letters in the same column are significantly different according to Duncan's multiple range test ( $\mathrm{p}<0.01$ ). 
Table 4. Water quality.

Cuadro 4. Calidad de agua.

\begin{tabular}{|c|c|c|c|c|c|}
\hline & $\begin{array}{c}\mathrm{EC}^{1} \\
\mathrm{ds} \cdot \mathrm{m}^{-1}\end{array}$ & $\mathrm{pH}$ & $\begin{array}{l}\mathrm{SAR}^{1} \\
\text { ratio }\end{array}$ & $\begin{array}{l}\mathrm{RSC}^{1} \\
\mathrm{me} \cdot \mathrm{L}^{-1}\end{array}$ & Classification \\
\hline Average & 0.78 & 8.26 & 9.98 & 5.99 & $\mathrm{C} 3 \mathrm{~S}^{2}$ \\
\hline Maximum & 1.04 & 9.0 & 18.4 & 8.5 & $\mathrm{C} 2 \mathrm{~S}^{1}$ \\
\hline Minimum & 0.63 & 7.0 & 4.0 & 3.2 & $\mathrm{C} 2 \mathrm{~S}^{1}$ \\
\hline
\end{tabular}

${ }^{1} \mathrm{EC}$, electrical conductivity; SAR, sodium adsorption ratio; RSC, residual sodium carbonate.

soil chemical response to irrigation suggest that the sodication process must be controlled in long-term continuous agriculture under supplementary irrigation. Rainfall simulation data shows a higher susceptibility to water erosion by rain in irrigated soils. Finally, a sustainable high production system requires enhanced soil erosion control.

\section{Resumen}

En 21 localidades del norte de la región pampaena de Argentina se estudiaron los efectos del riego suplementario sobre las propiedades químicas y físicas del suelo. Los parámetros químicos y físicos se midieron entre 0 y $100 \mathrm{~mm}$ en los suelos con y sin riego suplementario. Los parámetros químicos del suelo considerados fueron: conductividad eléctrica (CE), $\mathrm{pH}$, porcentaje de sodio intercambiable (PSI) y materia orgánica. Los parámetros físicos: estabilidad de estructura índice de percolación de laboratorio infiltración a campo, escurrimiento y pérdida de suelo, con un micro simulador de lluvia portátil. En suelos bajo riego, los análisis químicos mostraron un pequeño incremento del PSI, de 2.56 a 5.52 y en $\mathrm{pH}$, de 6.13 a 6.45 , respecto a los suelos sin riegos. Sin embargo, la CE se mantuvo en los mismos valores para ambos sistemas. La aplicación de lluvia simulada de $30 \mathrm{~mm}$ por 30 min mostró diferentes comportamientos del suelo. Los suelos bajo riego dieron valores menores de entrada de agua y de tasa de infiltración, y mayores valores de escurrimiento y pérdida de suelo. La variación de las propiedades químicas y físicas de los suelos después de 10 años de riego suplementario, muestra que se ha producido un avance moderado de los procesos de sodificación y alcalinización. La calidad del agua de riego y los parámetros químicos de los suelos bajo riego, sugieren que el proceso de sodificación y el incremento del riesgo de erosión deben ser controlados para mantener un sistema de alta productividad.

Palabras clave: Infiltración, riego suplementario, riesgo de erosión, sodificación.

\section{References}

Abu-Awwad, M., and A. Kharabsheh. 2000. Influence of supplemental irrigation and soil surface furrowing on barley yield in arid areas affected by surface crust. Journal of Arid Environments 46:227-237.

Al-Zu'bi, Y. 2007. Effect of irrigation water on agricultural soil in Jordan valley: An example from arid area conditions. Journal of Arid Environments 7:63-79.

Botta, G., D. Jorajuria, R. Balbuena, M. Ressia, C. Ferrero, H. Rosatto, and M. Tourn. 2006. Deep tillage and traffic effects on subsoil compaction and sunflower (Helianthus annus L.) yields. Soil and Tillage Research 91:164-172.

Boivin, P., F. Favre, C. Hammecker, L. Maeght, J. Delarivière, J. Poussin, and M. Wopereis. 2002. Processes driving soil solution chemistry in a flooded rice-cropped vertisol: analysis of longtime monitoring data. Geoderma 110:87-107.

Cerana, J.A. 1980. Deterioro de los suelos a consecuencia de riegos con aguas poco salinas que contienen bicarbonatos. IX Reunión Argentina de la Ciencia del Suelo. Paraná, Argentina.

Chen, Y., and A. Banin. 1975. Scanning electron microscope (SEM) observations of soil structure changes induced by sodium-calcium exchange in relation to hydraulic conductivity. Soil Science 120:428-436.

Costa, J.L. 2000. Effect of Irrigation Water Quality Under supplementary irrigation on soil chemical and physical properties in the "southern humid pampas" of Argentina. Journal of Crop Production 2:85-99.

Dane, H., and A. Klute. 1977. Salts effects on the hydraulic properties of a swelling soil. Soil Science Society American Journal 42:32-39.

De Boodt, M., and L. De Leenheer. 1967. West european methods for soil structure determinations. The St. Faculty Agromical Science 7 Ghent: 60-62, Belgium.

Génova, L.J. 1993. Estudio de la degradación de suelos bajo riego complementario de cultivos extensivos con aguas subterráneas del aquífero pampeano en el norte de Buenos Aires. XIV 
Congreso Argentino de la Ciencia del Suelo, Mendoza, Argentina.

Henin, S., R. Gras, and G. Monnier. 1969. Le Profil Cultural. Létat Physique du sol et ses conséquences agronomiques. Masson et Cie, Editeurs. Paris, France. 325 pp.

Herrero, J., and O. Perez Covetta. 2005. Soil salinity changes over 24 years in a Mediterranean irrigated district. Geoderma 125:287-308.

INTA, 1972. Cartas de Suelos de la República Argentina, Hoja 3360-32 (Pergamino) y Hoja 3363-66 y hoja 3163-32 (Oncativo). Instituto Nacional de Tecnología Agropecuaria, INTA, Buenos Aires, Argentina.

Irurtia, C., and R. Mon, R.. 1994. Microsimulador de lluvia para derterminar infiltración a campo. Instituto de Suelos, INTA. Castelar, Argentina.

Kamphorst, A., and G.H. Bolt. 1978. Saline and sodic soils. Pages 160 - 188. In: G.H. Bolt and M.G.M. Bruggenwert (eds.). Soil Chemistry. A. Basic Elements. Elsevier Publishing Company. Amsterdam. The Netherlands. 423 pp.
Shainberg, I. 1984. Reclamation of sodic soils. Pages 221-236. In: Soil Salinity Under Irrigation. Processes and Management. Shainberg-Shalvet (eds.) Berlin, Germany.

Suarez, D., J. Wood, and M. Lesh. 2006. Effect of SAR on water infiltration under a sequential rain-irrigation management system. Agricultural Water Management 86:150-164.

Truman, C., and D. Rowland. 2005. Conservation tillage to manage water and supplemental irrigation. Pages 25-27. In: Georgia. Proceedings of the 2005 Georgia Water Resources Conference, Kathryn J. Hatcher editor. University of Georgia, Athens, GA.

USDA. 1954. U.S. Salinity Laboratory Staff. Diagnosis and Improvement of Saline and Alkali Soils. USDA Agric. Handbook $N^{\circ} 60$. USA.

Wakley, A. and I. A. Black. 1964. Chemical Composition of Soils. Chemistry of the Soil. $2^{\circ}$ Ed. F. E. Bear Reinhold Publishing Company New York, USA. pp. 71-141. 